4 Y. Asensio, C.M. Fernandez-Marchante, J. Lobato, P. Cañizares, M.A. Rodrigo*

5

6

7

8

9 Abstract

\section{Influence of the fuel and dosage on the performance of double-} compartment microbial fuel cells

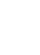

6 Department of Chemical Engineering. Faculty of Chemical Sciences \& Technologies.

7 Universidad de Castilla La Mancha. Campus Universitario s/n 13071 Ciudad Real. Spain. 8

In the search for novel application of bio-electrochemical devices technology, This manuscript focuses on the evaluation of the use of different types and dosages of fuels in the performance of double-compartment microbial fuel cell equipped with carbon felt electrodes and cationic membrane. Five types of fuels (ethanol, glycerol, acetate, propionate and fructose) have been tested for the same organic load (5000 mg L $\mathrm{L}^{-1}$ measured as COD) and for one of them (acetate), the range of dosages between 500$20000 \mathrm{mg} \mathrm{L}^{-1}$ of COD was also studied. Results demonstrate that production of electricity depends strongly on the fuel used. Carboxylic acids are much more efficient than alcohols or fructose for the same organic load and within the range $500-5000 \mathrm{mg} \mathrm{L}^{-1}$ of acetate the production of electricity increases linearly with the amount of acetate fed but over these concentrations a change in the population composition may explain a worse performance.

\section{Keywords}

Microbial fuel cells; fuel; organic load; substrate; acetate

\section{Highlights}


38

39

40

41

- Production of electricity increases linearly with COD in the range 500-5000 ppm

- Carboxylic acids are more efficient fuels for the production of electricity than alcohols

- Fructose behaves as a very low-efficient fuel for MFC

- Maximum power density attainable in the range $20-500 \mathrm{~mW} \mathrm{~m}^{-2}$ depending on the composition of fuel

- Propionic acid are slightly more efficient than acetic acid as fuel 


\section{Introduction}

For a very long time, microbial fuel cells (MFC) have been studied as promising substitutive technologies for the biological reactor of conventional municipal wastewater treatment plants (Logan et al. 2006, Rodrigo et al. 2007). In a parallel application, they have also been considered for the treatment of highly-loaded industrial effluents ( Logan et al. 2006, Huang et al. 2009, Cusick et al. 2010). Results were promising at the lowest scale, but unfortunately, the scale-up of this bio-electrochemical technology is a huge handicap nowadays and much work has to be carried out in the next years in order to overcome it successfully (Virdis et al. 2008).

This bio-electrochemical technology is not easy and researchers are now realizing it. This point can be explained taking into account that, in fact, it consists of the combination of two very different technologies: fuel cells based on the electrochemistry and organic biodegradation based on biotechnology. The difficult coupling of these two different disciplines can help to explain the necessity of further research and the need for great efforts in order to find a ready-to-use technology. Currently, There is a great deal of papers focused on trying to improve the performance of microbial fuel cell and, particularly, their efficiency (Rabaey et al. 2003). Topics of interest include the electrode materials, fuel cell mechanical design and use of different types of synthetic solutions or real wastewater as fuel (Kim et al. 2015, Lee et al. 2015).

This last topic is of a great relevance because, perhaps, the environmental application looked for in the last years is not the best choice for this type of energy conversion devices. In turn, the power supply to systems with a low energy requirement in remote applications could have greater real opportunities. Within this context, the perspective of feeding the MFC with a synthetic fuel, manufactured only to harvest energy from organic matter can be a way to optimize these devices. Obviously, due to the metabolic 
requirements, the fuel used should be a solution containing not only a carbon source but also nutrients in ratios enough to do not become the limiting reagents of the process, such as happens naturally with the wastewater types typically fed to these systems (Rodrigo et al. 2009a).

There are many types of potential fuels for MFC (Oh and Logan 2005, Virdis et al. 2010). Obviously, the simpler the molecule the easier and more effective is the resulting process, because complex molecules should be hydrolyzed before they can be oxidized by microorganisms. Metabolism of sugars, alcohols and carboxylic acids proceeds through very different pathways, for which the redox transfer enzymes and/or redox mediators involved can be very different and these differences should reflect on the performance of a MFC. It is important to know which of this carbon sources provides a higher efficiency, in the search for new applications of the technology. Hence, although typically, MFC have been studied as alternative for wastewater treatment processes, this application, although promising, is perhaps not the best choice because of the low power yielded by these devices. In the search for new applications of the technology, it is interesting to evaluate their performance with different synthetic fuels and in different concentrations, trying to determine the fuel that produces the highest efficiency. The substrate also plays another important role in MFC (Lobato et al. 2012) helping to select population and hence to the development of optimal biofilms (Chae et al. 2009, Liu et al. 2009). A great variety of substrates can be used in MFCs for electricity production ranging from pure compounds such as glucose, acetate, butyrate, lactate, ethanol (Rabaey and Verstraete 2005) to complex mixtures of organic matter present in wastewater ( Rodrigo et al. 2009a, Pant et al. 2010). The electrogenic bacteria are only capable of completely oxidizing non-fermentable substrates such as acetate by electricity 
production, while the fermentative bacteria convert carbohydrates into short-chain fatty acids such as acetate (Lovley 2008).

Careful control of the substrate feed can thus be used to optimize the biofilm and in turn the electricity generation. These substrates include pure and non-fermentable ones such as acetate and lactate (Bond and Lovley 2003, Rabaey et al. 2003) in addition to fermentable ones such as glucoses and xylose (Huang and Angelidaki 2008, Ishii et al. 2008, Rezaei et al. 2009, Makinen et al. 2013). Mixed substrates present in mixed inoculum feeds such as domestic and industrial wastewater, which contain fatty acids, protein, and carbohydrates, have also been studied (Feng et al. 2008).

With this background, the goal of this work has been to evaluate the best organic load, within the range 500-5000 ppm of acetate, and the best type of fuel, within a set that includes carboxylic acids, alcohols and sugars, in order to get information for the application of the technology in different fields, not only wastewater treatment but also in sensors and other devices.

\section{Materials and methods}

Microbial fuel cell. The set-up used in this work consisted of a MFC with two chambers $\left(4 \mathrm{~cm}^{3}\right.$ volume each one) separated by a proton exchange membrane, PEM (Sterion $\left.{ }^{\circledR}\right)$, which has a high ionic conductivity $\left(0.9-0.02 \mathrm{meq}^{-1}\right)$ and low electronic conductivity (8 $\mathrm{x} 10^{-2} \mathrm{~S} \mathrm{~cm}^{-1}$. MFC is formed by two HDL (high pressure laminate) plates and two silicon plates to improve the mechanical properties and avoid liquid losses. Carbon felts (KFA10, SGL Carbon Group®) were used as electrodes in both chambers $\left(3 \mathrm{~cm}^{2}\right.$ each). The electrode spacing between the anode and the cathode was minimized in order to reduce as much as possible the internal electrical losses from the system. The two electrodes were connected by an external resistance (Rext) of $120 \Omega$; this low value was chosen to 
117 prevent activation losses and facilitate electron transfer during the acclimation period

118 (Rodrigo et al. 2009b). The MFCs were operated simultaneously in semi-continuous mode and at room temperature $\left(25 \pm 3^{\circ} \mathrm{C}\right)$. The cathode compartment of the MFC was connected to a water reservoir of $100 \mathrm{~cm}^{3}$ and a peristaltic pump was used to circulate an $\mathrm{HCl}$ solution $(\mathrm{pH} 3.5)$ from the reservoir through the cathode chamber of the MFC at 25 $\mathrm{cm}^{3} \mathrm{~min}^{-1}$. A fishery compressor that can provide a flow rate of $1.6 \mathrm{~L} \mathrm{~min}^{-1}$ and a maximum pressure of $1.2 \mathrm{~m}$ of water-column was connected to the cathode to supply oxygen to the cathodic chamber (Penteado et al., 2016).

Inoculum and synthetic wastewater. Activated sludge from a wastewater treatment plant (Ciudad Real, Spain) was used as the inoculum for the anodic compartment. The activated sludge of the biological reactors was placed in the anodic chamber for three days in a 1:2 ratio without aeration to favor the formation of a mixed culture of anaerobic microorganisms. In this period, no synthetic wastewater was supplied to feed the culture.

Table 1: Inorganic compounds in wastewater composition

Three types of carbon based fuels were studied: alcohols (ethanol and glycerol), a volatile

\subsection{7}

1.85

1.11

0.92

1.25

Ammonium iron (II) sulfate $\quad 0.07$

fatty acid (acetic and propionic acid) and a monosaccharide sugar (fructose). 
143 Table 2: COD $\left(\mathrm{mg} \mathrm{O}_{2} \mathrm{~L}^{-1}\right)$, concentration $\left(\mathrm{g} \mathrm{L}^{-1}\right)$, volume $\left(\mathrm{cm}^{-3}\right)$ and type of fuel used in the synthetic wastewater

\begin{tabular}{cccc}
\hline $\mathbf{C O D}\left(\mathbf{m g ~ O}_{\mathbf{2}} \mathbf{L}^{-\mathbf{1}}\right)$ & Fuel & {[]$\left(\mathbf{g ~ L}^{-\mathbf{1}}\right)$} & $\mathbf{V}\left(\mathbf{c m}^{\mathbf{3}} \mathbf{L}^{-\mathbf{1}}\right)$ \\
\hline 500 & Sodium acetate & 0.805 & - \\
1000 & Sodium acetate & 1.61 & - \\
2500 & Sodium acetate & 4.025 & - \\
5000 & Sodium acetate & 8.05 & - \\
10000 & Sodium acetate & 16.1 & - \\
20000 & Sodium acetate & 32.2 & - \\
5000 & Ethanol & - & 3.04 \\
5000 & Propionic acid & - & 3.34 \\
5000 & Glycerol & - & 3.26 \\
5000 & Fructose & 4.69 & - \\
\hline
\end{tabular}

145

146 It is worth to remind that although the MFC was fed only once a day, its operation mode can be considered as semi-continuous within long periods of time. HTR was 3.16 days in the different experiments. In all case no changes were made in the rest of parameters that may affect the performance of the cell, and even the nutrient solution was kept the same in the five test (concentrations of nutrients were checked to be high enough to not become limiting reagents).

Electrochemical and chemical measurements. A digital multimeter (Keithley 2000 multimeter) was connected to the system to monitor continuously the value of the cell

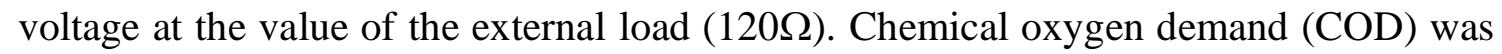
determined using a Velp ECO-16 digester and a Pharo 100 Merck spectrophotometer analyzer and $\mathrm{pH}$, conductivity and dissolved oxygen were measured with a GLP22 Crison pH meter, a Crison Cm 35 conductivity meter and an Oxi538 WTW oxy meter, respectively. Polarization curves have been done in MFC. Three important parameters were evaluated: the open circuit voltage (OCV) or the maximum allowable MFC voltage, 
161 the maximum intensity and the maximum power density of the MFC. In addition, the

162 shape of curves gives important information about the limiting processes, which control

163 the performance of the cell. Polarization curves can be divided into three zones: a decrease

164 of the current due to the activation loses, a linear decrease due to ohmic loses, and a third

165 zone that corresponds to the region controlled by mass-transfer (concentration loses).

167 Results and discussion

168

169 Figure 1 shows the changes in the COD monitored in the anode chamber of a divided

170 MFC during 2.5-month tests in which different fuels, made up with acetate at different

171 concentration, are fed in order to check the effect of the organic load on the performance

172 of the cell. Over the tests, the other inputs are kept constant, including hydraulic retention

173 time, temperature and external electric load of the cell. Likewise, the nutrient solution

was the same and it was checked that concentrations of all nutrient were high enough to

175 not become the limiting reagent in the performance of the MFCs. Hence, changes in these

176 experiments are expected to be only consequence of the organic load of the influent fed

177 to the MFCs. 


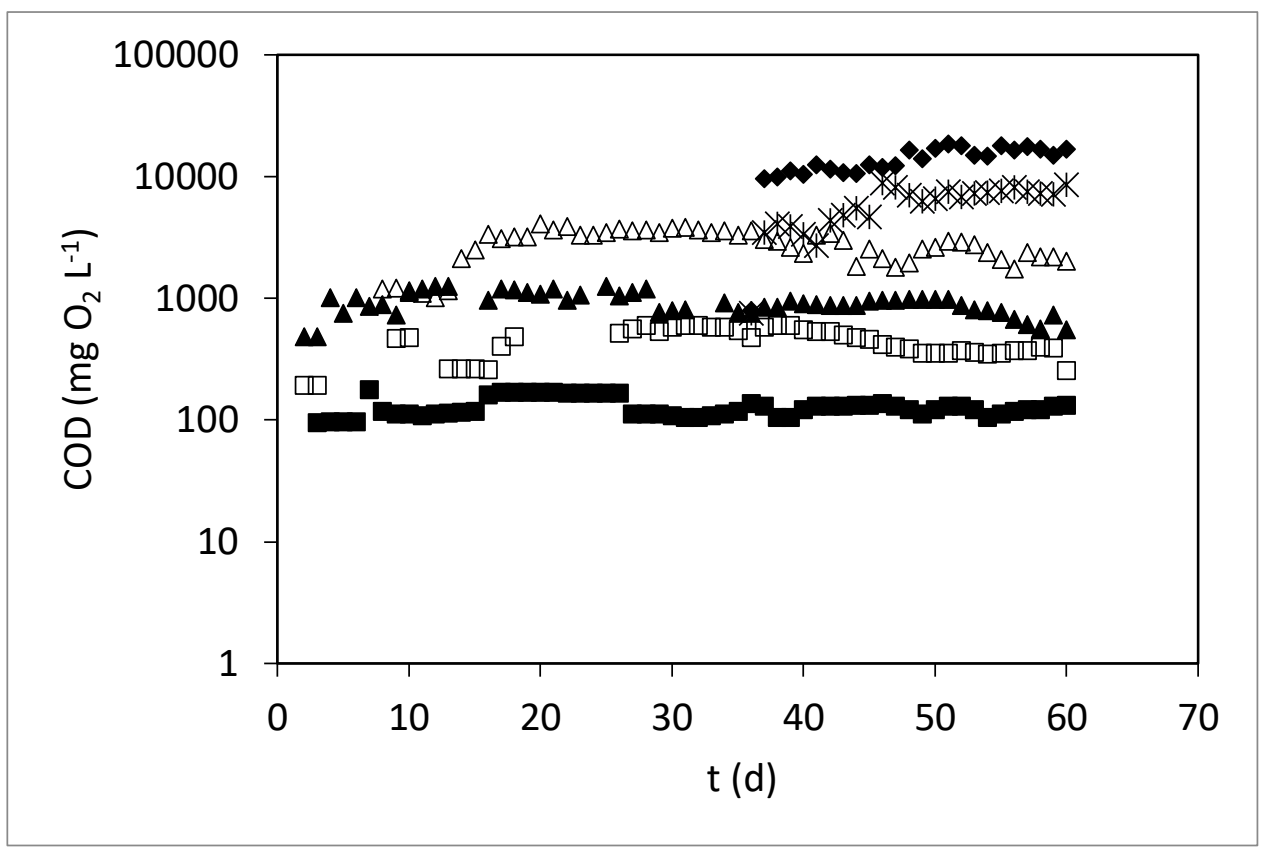

Figure 1. Changes in the COD during the tests. Operational conditions: Sodium acetate

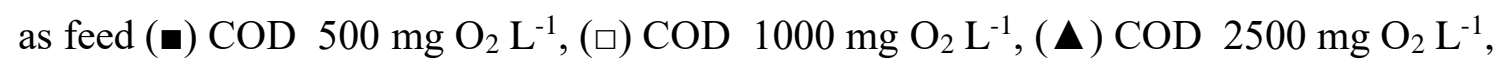

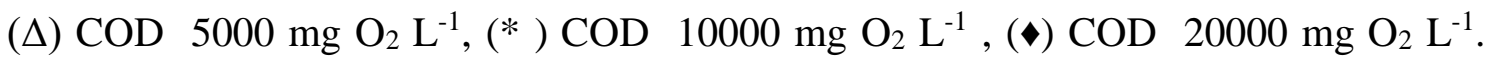
Average temperature: $27^{\circ} \mathrm{C}$

It is worth to remind that although the MFC was fed only once a day, its operation mode ean be considered as semi-continuous within long periods of time. This is confirmed by results obtained in this work. Thus, the Figure 1 shows how the COD remaining in the anode compartment changes up to a steady-state value that it is related to the concentration fed, in agreement to what it could be expected for a semi-continuous system. At this point, It is important to point out that the COD changes over the day in the cell because the cell is fed daily but what it is compared in the Figure is the value of COD taken at the end of the day before the replacement with fresh solution of acetate. It is also important to point out that the higher the concentration fed, the higher is the value of COD contained in the anode compartment 

in Figure 2.

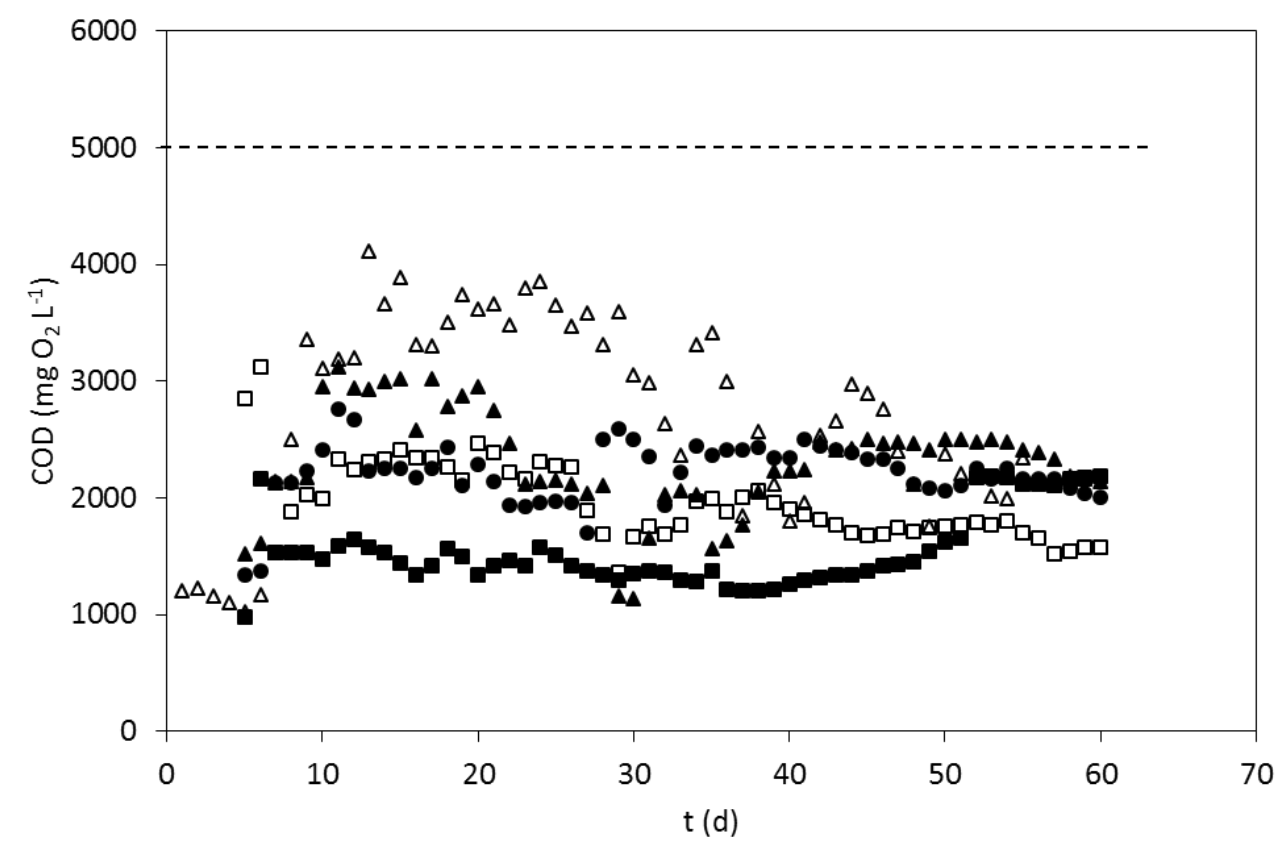

197

Figure 2. Changes in the COD during the tests. Operational conditions: $[C O D]_{0}=5000$ mg $\mathrm{O}_{2} \mathrm{~L}^{-1}$, Carbon felt as electrode material. (ロ) Ethanol, ( $\square$ ) Glycerol, ( $\boldsymbol{\Delta}$ ) Propionic acid, $(\Delta)$ Sodium acetate, $(\bullet)$ Fructose. Average temperature: $27^{\circ} \mathrm{C}$

In comparing the output of the tests, it can be observed a different time-course of the COD over the experiments, although at long times, the value of COD in the reactor tends to stabilize around $2000 \mathrm{ppm}$ in the five tests. It is important to point out how concentration of COD during the first days increases importantly in the tests in which the MFC were fed with carboxylic acids while it remains constants only increases more slowly with the fructose and the alcohols fuels. This increase may suggest a more difficult degradation of the substrate by the raw microorganism initially seeded to the anode chamber (which were obtained in the biological reactor of a municipal WWTP and hence were acclimated to urban wastewater that is very different from a carboxylic acid solution). This behavior reverses when the population was fully acclimated from the urban wastewater to the new 
212 substrate solution used as fuel (after several days of running the MFCs). Under those

213

214

215

216

217

218

219

220

221

222

223

224

225

226

227

228

229

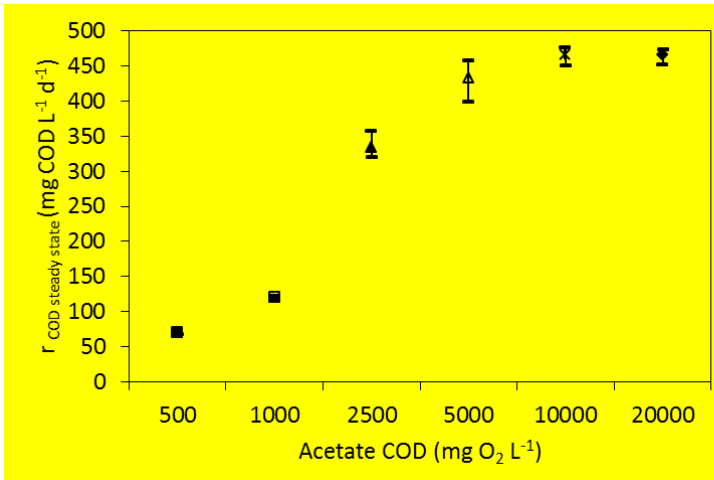
model (eq 2)

Opposite, to evaluate performance of short periods (time scale of hours), such as the daily changes of the COD, it is better to fit the performance of the cell to a discontinuous reactor

$$
r V=V \frac{d C_{1}}{d t}
$$

Taking into account this fact, reaction rates calculated by applying model shown in eq. 1 are plotted vs organic load and type of substrate in Figure 3.

Figure 3. COD consumption rate achieved in the steady state (a) at different COD concentrations of Sodium acetate, (b) with different types of substrates. Carbon felt used 
as electrode material. Organic load in part a: (匹) COD $500 \mathrm{mg} \mathrm{O}_{2} \mathrm{~L}^{-1}$, (口) COD 1000 $m g \mathrm{O}_{2} \mathrm{~L}^{-1},(\boldsymbol{\Delta}) \mathrm{COD} 2500 \mathrm{mg} \mathrm{O}_{2} \mathrm{~L}^{-1},(\Delta) \mathrm{COD} 5000 \mathrm{mg} \mathrm{O}_{2} \mathrm{~L}^{-1}$, ( ) COD $10000 \mathrm{mg} \mathrm{O}$ $\mathrm{L}^{-1}$, (») COD $20000 \mathrm{mg} \mathrm{O}_{2} \mathrm{~L}^{-1}$. Organic load in part b: COD: $5000 \mathrm{mg} \mathrm{O}_{2} \mathrm{~L}^{-1}$. Average temperature: $27^{\circ} \mathrm{C}$

In comparing the effect of organic load, it is observed a perfect Monod-type behavior with a maximum COD removal rate slightly over $450 \mathrm{mg} \mathrm{COD} \mathrm{L}^{-1} \mathrm{~d}^{-1}$, which is obtained

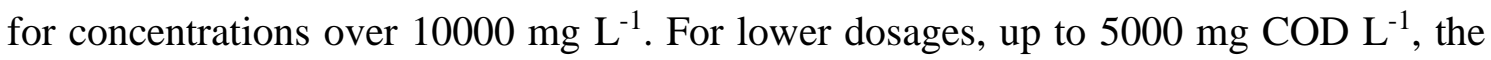
higher the amount of fuel, the higher is the degradation rate observed, with a clear first order kinetic behavior, which points out the linear dependence of the consumption of organics with the influent COD concentration. Regarding the reaction rates evaluated in the last stage of the test with different substrates, it is worth to point out that steady-state rates are within the range $450-650 \mathrm{mg} \mathrm{COD} \mathrm{L}^{-1} \mathrm{~d}^{-1}$. Values obtained for carboxylic acids are slightly lower and the highest rate is attained with the use of fructose as fuel.

It is important to remind that the MFCs were seeded with the same aerobic sludge and that conditions in the anodic chamber are anaerobic, because concentration of oxygen is nil, although metabolisms of aerobic microorganism adapted to use other sinks of electrons (both, directly on electrode surface or mediated processes) should still be aerobic.

COD changes inform about the globalized metabolism of the microorganisms contained in the anode compartment but not about the behavior of electrogenic microorganisms, because both electrogenic and non-electrogenic microorganisms are expected to consume COD. In order to evaluate the performance of electrogenic microorganisms, the electric current produced is the best indicative parameter. This parameter is shown in Figure 4, where it can be clearly seen how the current produced increases over the test up to reach 

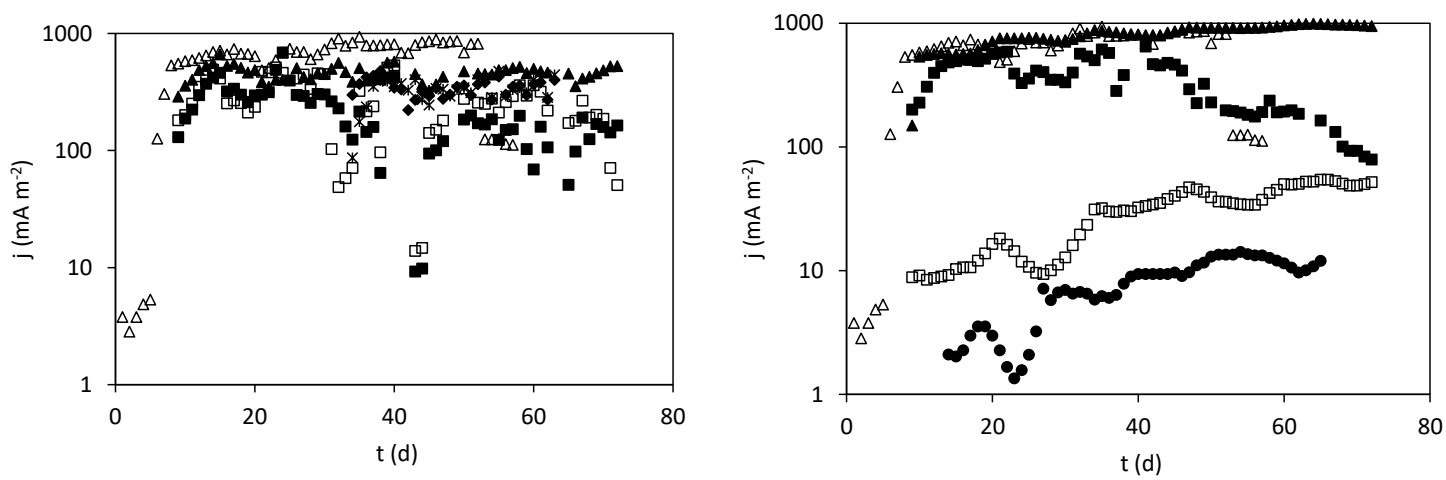

Figure 4. Current density produced in the MFC over the different tests carried out in this work. Part a. Current densities profiles observed in MFC. (ロ) COD $500 \mathrm{mg} \mathrm{O}_{2} \mathrm{~L}^{-1}$, ( $\square$ )

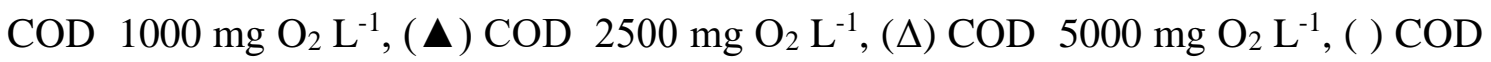
$10000 \mathrm{mg} \mathrm{O}_{2} \mathrm{~L}^{-1},(\diamond)$ COD $20000 \mathrm{mg} \mathrm{O}_{2} \mathrm{~L}^{-1}$. Part b. Current densities profiles observed in MFC under different types of feed nutrients. ( $\square$ ) Ethanol, ( $\square$ ) Glycerol, ( $\mathbf{\Delta}$ ) Propionic acid, $(\Delta)$ Sodium acetate, $(\bullet)$ Fructose. COD: $5000 \mathrm{mg} \mathrm{O}_{2} \mathrm{~L}^{-1}$. Average temperature: $27^{\circ} \mathrm{C}$

This general behavior is obtained in all tests, regardless of using different organic loads with the same substrate (part a) or different substrates with the same organic load (part b). Differences become more important in the comparison of substrates, which clearly points out that carboxylic acids are more efficient fuels than alcohols and fructose. This

271 is observed in Figure 5, where the steady-state values reached in each test are compared and it is an indication that carboxylic acids are better fuels than less oxidized molecules such as alcohols or sugars. 


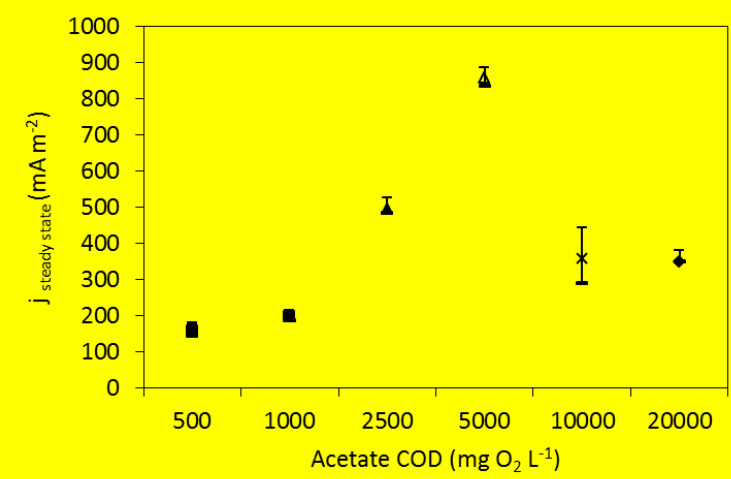
Average temperature: $27^{\circ} \mathrm{C}$

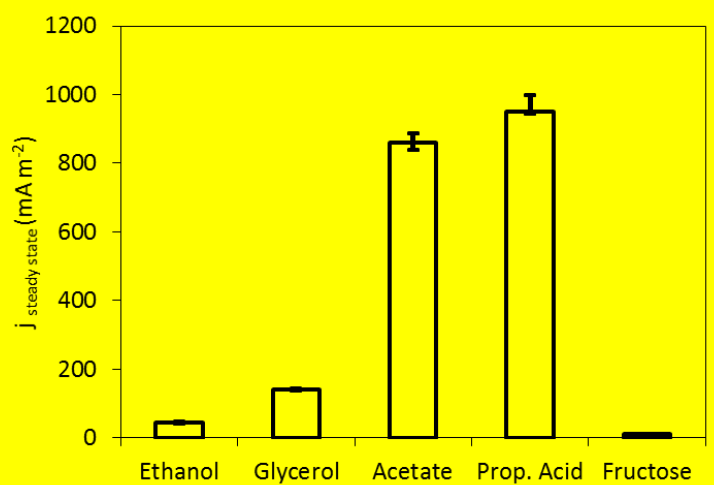

Figure 5. Steady-state electric current density produced in double compartment MFC fed with (a) different COD concentrations of Sodium acetate, (b) different types of fuels. Operational conditions: Carbon felt as electrode material. Part a: (ש) COD $500 \mathrm{mg} \mathrm{O}_{2} \mathrm{~L}^{-}$ 1, (口) COD $1000 \mathrm{mg} \mathrm{O}_{2} \mathrm{~L}^{-1},(\boldsymbol{\Delta}) \operatorname{COD} 2500 \mathrm{mg} \mathrm{O}_{2} \mathrm{~L}^{-1},(\Delta) \mathrm{COD} 5000 \mathrm{mg} \mathrm{O}_{2} \mathrm{~L}^{-1}$, (*) COD $10000 \mathrm{mg} \mathrm{O}_{2} \mathrm{~L}^{-1}$, (») COD $20000 \mathrm{mg} \mathrm{O} \mathrm{L}^{-1}$ Part b: COD $5000 \mathrm{mg} \mathrm{O}_{2} \mathrm{~L}^{-1}$.

Another interesting information that can be drawn from this Figure is the effect of the organic load, because opposite to what it was shown with the COD consumption rate (which fitted well to a Monod Type behavior), the changes observed in this electrochemical parameter are different. There is a linear increase in the current density within the range 500-5000 $\mathrm{mg} \mathrm{L}^{-1}$ and then, for the two highest organic loadings, the current produced decrease substantially. Both changes behaviors-have an equivalent region in the $\mathrm{r}_{\mathrm{COD}} \mathrm{vs}$ operation time plot, although in the comparison it was expected a higher value of the current density in the tests fed with concentrations over $5000 \mathrm{mg} \mathrm{L}^{-1}$. Thus, the linear increase in the COD and $\mathrm{j}$ for concentrations under $5000 \mathrm{mg} \mathrm{L}^{-1}$ can be explained by assuming the same biological culture is operating in all test, because the ratio current produced/COD consumed is kept constant. Opposite, higher concentrations of COD should lead to a change in the microorganisms composition, with a lower population of electrogenic microorganisms and hence, despite the COD consumption is 
maintained in the highest rate, the production of electricity can become significantly lower. It is important to take in mind that Current density informs directly about the rate of the electrochemical processes. As COD is also a quantification of the organic content and it requires four electrons to be transformed into carbon dioxide, the ratio in the same units of $\mathrm{j}$ and $\mathrm{r}_{\mathrm{COD}}$ is an efficiency measurement (in fact, it is the well-known coulombic efficiency), which is also directly related with the population of bioelectrogenic microorganism, at least from the viewpoint of COD consumption.

$$
\text { efficiency }=\frac{j\left(\frac{m A}{m^{2}}\right) \cdot A\left(m^{2}\right)}{r\left(\frac{m g C O D}{L \cdot d}\right) \cdot V(L) \cdot\left(\frac{1 m m o l \operatorname{CoD}}{32 m g \operatorname{COD}}\right) \cdot\left(\frac{4 m \text { mol } e^{-}}{1 \text { mmolCOD }}\right) \cdot\left(\frac{96500 \mathrm{mC}}{1 \text { mmole }}\right) \cdot\left(\frac{1 d}{86400 s}\right)}
$$

This value is approximately kept constant within the range $500-5000 \mathrm{mg} \mathrm{L}^{-1}$ in a value of 9.24\% and c.a. $3.82 \%$ for higher doses, suggesting indicating that concentration of electrogenics is three times higher for the cultures acclimated at the lowest range of COD. Regarding the influence of the type of fuel (for the same loading rate of $5000 \mathrm{mg} \mathrm{L}^{-1}$ ), application of eq. 3 results in values near $10 \%$ for both carboxylic acids. These values are reduced to $1.31,0.41$ and $0.09 \%$, respectively for glycerol, ethanol and fructose, respectively, pointing out the prevalence of non-electrogenic populations with those substrates.

Another important point to be studied in the performance of MFC is the cathodic reactions. The cathodic reactions play an important role in the performance of the MFC. They consists of the reduction of oxygen to water on the surface of the cathode and hence it is not a biological but an abiotic process. Membrane used in the electrochemical cell prevents the crossing of oxygen molecules to the anode compartment(Lobato et al. 2012), improving in this way the efficiency of the MFC because the only sink of electrons available for the oxidation of the COD in the anode chamber is the anode surface. Hence, 
initially it could be expected than the rate of the anode and cathode processes should be related, in particular if a pure electrochemical process is developed in the cell and other side processes do not affect oxygen. In order to evaluate this important point, oxygen consumption rates were evaluated in the cathode chamber. This measurement was carried out by turning off the oxygen flow fed to the cathode chamber and measuring the oxygen decay (Rodrigo et al. 2010). Results are shown in Figure 6, where it can be seen that except for the tests carried out in the MFC fed with the lowest organic load, the oxygen consumption rate varies in a similar way than the current intensity produced in the cell. Discrepancies can be related to non-electrochemical oxygen consumptions such as desorption of oversaturated oxygen or the growth of microorganism in the cathode chamber and to side electrochemical processes like corrosion of the carbon felt or production of hydrogen peroxide instead of water as a reaction product of the cathode reaction.
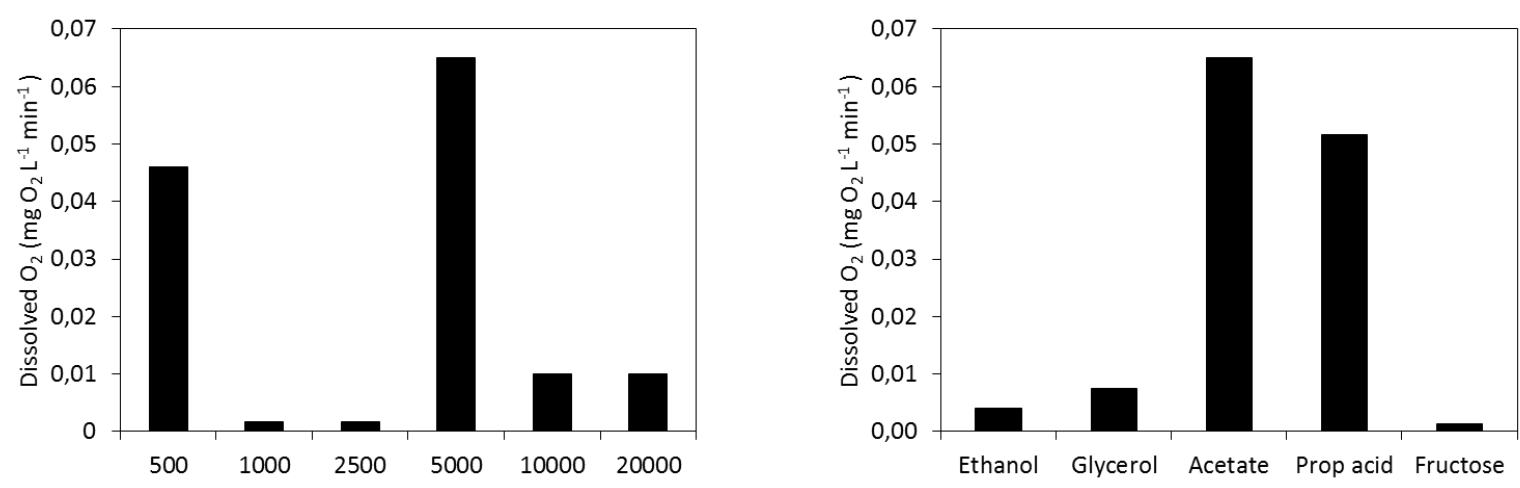

Figure 6. Oxygen consumption rate in the cathode chamber. (a) different COD concentrations of sodium acetate, (b) different types of fuel. Average temperature: $27^{\circ} \mathrm{C}$

The polarization curves give To know more details about the electrochemistry of the microbial fuel cells, it is important to focus on the results of a very important test: the pelarization curves. The plots obtained during the $55^{\text {th }}$ day of operation (when the system 
is completely stabilized) are compared in Figures 7 (voltage vs current plot) and 8 (power vs current plot).

As it can be observed, there are only two zones in the polarization curves. This is a common observation in most MFC which contrast to the three zones typically observed in conventional fuel cells (polarization, ohmic and mass transfer loses). The open circuit potential is not the same despite the electrode materials were the same in all test, pointing out the differences in the oxidation and reduction reactions that develop in each cell. The most important remark is the much better performance of the cells fed with propionic and acetic acid, which according to the slopes of the second zone can be explained by a much lower ohmic resistance of the cell.
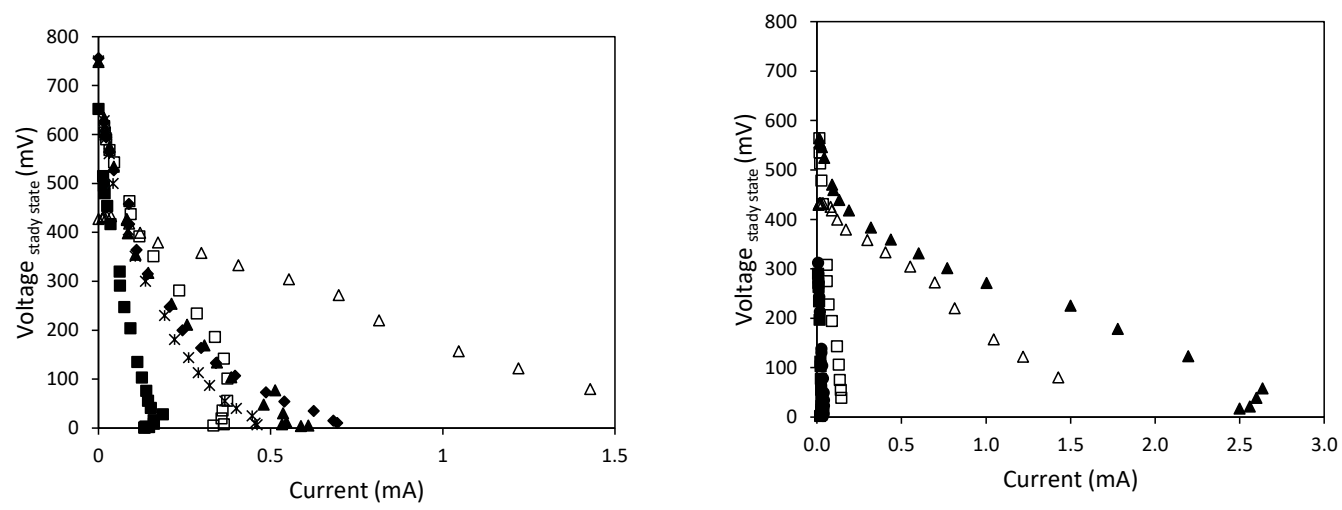

350

Figure 7. V vs current polarization curves obtained in the steady state. Operational conditions: Carbon felt as electrode material. Part a: (匹) COD $500 \mathrm{mg} \mathrm{O}_{2} \mathrm{~L}^{-1}$, (口) COD $1000 \mathrm{mg} \mathrm{O}_{2} \mathrm{~L}^{-1},(\boldsymbol{\Delta}) \operatorname{COD} 2500 \mathrm{mg} \mathrm{O}_{2} \mathrm{~L}^{-1},(\Delta) \operatorname{COD} 5000 \mathrm{mg} \mathrm{O}_{2} \mathrm{~L}^{-1}$, ( ) COD 10000

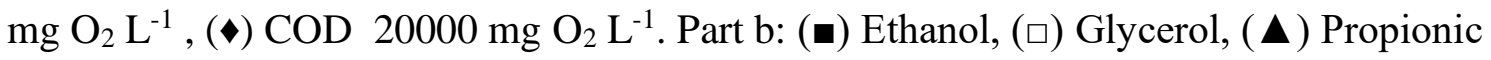
acid, $(\Delta)$ Sodium acetate, $(\bullet)$ Fructose. Average temperature: $27^{\circ} \mathrm{C}$ 

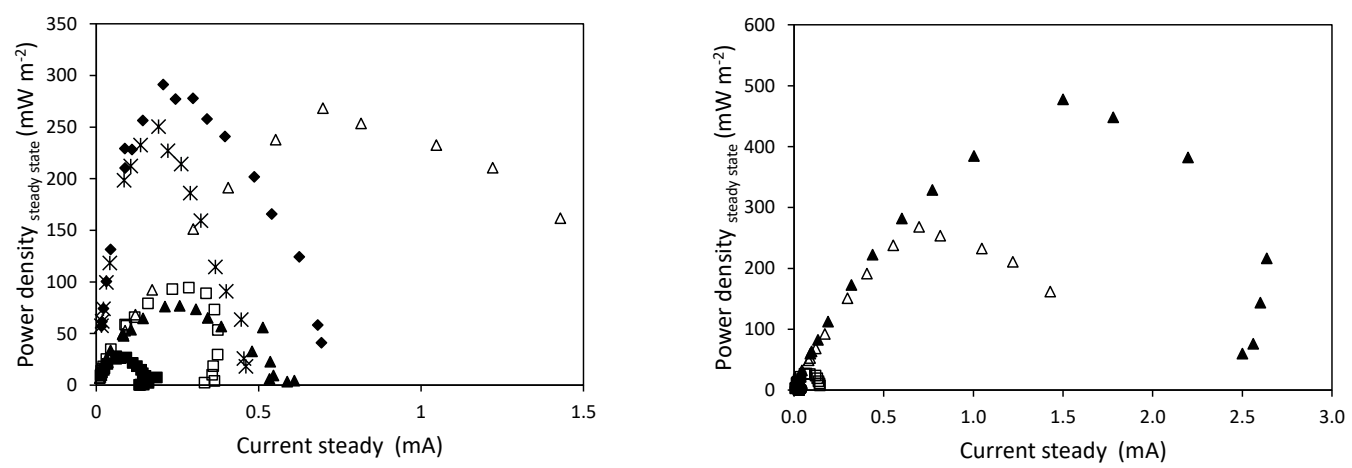

358

359 Figure 8. Power vs. current polarization curves in the steady state. Operational conditions: Carbon felt as electrode material. Part a: (ロ) COD $500 \mathrm{mg} \mathrm{O}_{2} \mathrm{~L}^{-1}$, (口) COD $1000 \mathrm{mg} \mathrm{O}_{2} \mathrm{~L}^{-1},(\boldsymbol{\Delta}) \mathrm{COD} 2500 \mathrm{mg} \mathrm{O} \mathrm{L}^{-1},(\Delta) \operatorname{COD} 5000 \mathrm{mg} \mathrm{O}_{2} \mathrm{~L}^{-1}$, (*) COD 10000

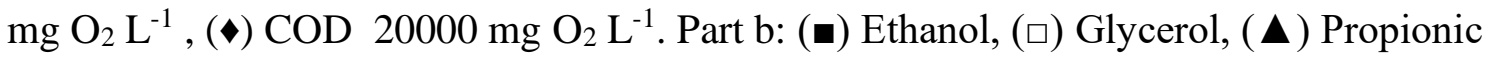
acid, $(\Delta)$ Sodium acetate, $(\bullet)$ Fructose. Average temperature: $27^{\circ} \mathrm{C}$

Regarding the maximum power attainable by these devices, it can be seen that in each case they are within the range $40-500 \mathrm{~mW} \mathrm{~m}^{-2}$. Maximum values are obtained for the two carboxylic acids, being higher in the case of the microbial fuel cell fed with propionic acid. It is important to point out that the maximum power obtained in the three reactors fed with organic loads over $5000 \mathrm{mg} \mathrm{L}^{-1}$ of acetate are nearly the same. However, they are obtained for lower current intensities at higher concentration. To compare these results with those shown in the literature, Table 3 presents a comprehensive list of substrates that have been used in MFC studies together with the reported maximum power density. At this point, It is important to point out that it is difficult to compare MFC performances from literature, due to different operating conditions, surface area and type of electrodes and different microorganisms involved and hence only relative comparison within the same manuscript should be carried out 
379 Table 3. Comparison of maximum power density and type of feeding solution.

\begin{tabular}{|c|c|c|}
\hline & Type of substrate & $\begin{array}{c}\text { Power density } \\
\left(\mathrm{mW} / \mathrm{m}^{2}\right)\end{array}$ \\
\hline $\begin{array}{l}\text { Liu et al., } 2005 \text { (Liu et al. } \\
2005 \text { ) }\end{array}$ & $\begin{array}{c}\text { Acetate } \\
\text { Glucose } \\
\text { Butyrate } \\
\text { Ethanol } \\
\text { Domestic waster }\end{array}$ & $\begin{array}{l}506 \\
494 \\
305 \\
488 \\
146\end{array}$ \\
\hline $\begin{array}{l}\text { Oh and Logan, } 2005 \text { (Oh } \\
\text { and Logan 2005) }\end{array}$ & $\begin{array}{c}\text { Acetate } \\
\text { Propionate }\end{array}$ & $\begin{array}{l}88 \\
67\end{array}$ \\
\hline $\begin{array}{l}\text { Ahn and Logan, } 2010 \\
\text { (Ahn and Logan 2010) }\end{array}$ & $\begin{array}{c}\text { Acetate } \\
\text { Butirate } \\
\text { Domestic water }\end{array}$ & $\begin{array}{l}549 \\
487 \\
302\end{array}$ \\
\hline $\begin{array}{l}\text { Catal et al., } 2008 \text { (Catal et } \\
\text { al. 2008) }\end{array}$ & $\begin{array}{c}\text { Glucose } \\
\text { Galactose } \\
\text { Fructose } \\
\text { Fucose } \\
\text { Rhamnose } \\
\text { Mannose } \\
\text { Xylose } \\
\text { Arbinose } \\
\text { Ribose } \\
\text { Galacturonic acid } \\
\text { Gucuronic acid } \\
\text { Gluconic acid }\end{array}$ & $\begin{array}{c}2160 \\
2090 \\
1810 \\
1760 \\
1320 \\
1240 \\
2330 \\
2030 \\
1520 \\
140 \\
2770 \\
2050\end{array}$ \\
\hline $\begin{array}{l}\text { Sun et al., 2015(Sun et al. } \\
\text { 2015) }\end{array}$ & $\begin{array}{c}\text { Acetate } \\
\text { Acetate /Xylose 1:1 } \\
\text { Xylose } \\
\text { ethanol(xylose) } \\
\end{array}$ & $\begin{array}{c}450 \\
300 \\
280 \\
80 \\
\end{array}$ \\
\hline $\begin{array}{l}\text { Kim et al., } 2007 \text { (Kim et } \\
\text { al. 2007) }\end{array}$ & $\begin{array}{c}\text { Ethanol (single-chamber) } \\
\text { Ethanol (two-chamber) }\end{array}$ & $\begin{array}{c}40 \\
488\end{array}$ \\
\hline $\begin{array}{l}\text { Yu et al., 2012(Yu et al. } \\
\text { 2012) }\end{array}$ & $\begin{array}{l}\text { Glucose (HTR } 12 \mathrm{~h} \text { ) } \\
\text { Glucose (HTR } 10 \mathrm{~h}) \\
\text { Glucose (HTR } 8 \text { h) } \\
\text { Glucose (HTR } 6 \text { h) }\end{array}$ & $\begin{array}{l}191 \\
351 \\
557 \\
753\end{array}$ \\
\hline
\end{tabular}




\begin{tabular}{|ccc|}
\hline This study & Acetate & 268 \\
& Propionic acid & 478 \\
& Ethanol & 100 \\
glycerol & 40 \\
& Fructose & 20 \\
\hline
\end{tabular}

381 Accordingly, our results are in agreement with those shown in the literature and points out that carboxylic acids are the best choice as substrate for MFC. However, opposite to several of the works reported, propionic improves slightly significantly the performance obtained by acetic acid. Both propionic and acetic acid can be easily obtained by biodegradation processes which can be easily coupled to MFC and this points becomes a promising approach for future MFC developments.

\section{Conclusions}

From this work the following conclusions can be drawn:

- There is a clear effect of the type of organic fed to MFC on the production of electricity. For the same organic load, carboxylic acids are the most efficient fuels in comparison to single sugars (like fructose) or alcohols (like ethanol or glycerol)

- For a system fed with acetate solution, there is a linear increase in the production of electricity with the organic load fed up to $5000 \mathrm{ppm}$ of COD. The ratio between the consumption of COD and the production of electricity is kept approximately constant in a value that indicates that around $9.24 \%$ of the COD is used to produce electricity, which can be interpreted in terms of a constant ratio of the bioelectrogenic population in the sludge. For higher COD fed, the ratio decreases to $3.82 \%$ indicating that extremely high loads lead to a change in the population of adapted microorganisms with a lower weight of bioelectrogenic microorganisms. 


\section{References}

Ahn, Y. and Logan, B.E. (2010) Effectiveness of domestic wastewater treatment using microbial Bond, D.R. and Lovley, D.R. (2003) Electricity production by Geobacter sulfurreducens attached to electrodes. Applied and Environmental Microbiology 69(3), 1548-1555.

Catal, T., Li, K., Bermek, H. and Liu, H. (2008) Electricity production from twelve monosaccharides using microbial fuel cells. Journal of Power Sources 175(1), 196-200.

Chae, K.-J., Choi, M.-J., Lee, J.-W., Kim, K.-Y. and Kim, I.S. (2009) Effect of different substrates on the performance, bacterial diversity, and bacterial viability in microbial fuel cells. Bioresource Technology 100(14), 3518-3525.

Cusick, R.D., Kiely, P.D. and Logan, B.E. (2010) A monetary comparison of energy recovered from microbial fuel cells and microbial electrolysis cells fed winery or domestic wastewaters. International Journal of Hydrogen Energy 35(17), 8855-8861.

Dumas, C., Basseguy, R. and Bergel, A. (2008) Microbial electrocatalysis with Geobacter sulfurreducens biofilm on stainless steel cathodes. Electrochimica Acta 53(5), 2494-2500.

Feng, Y., Wang, X., Logan, B.E. and Lee, H. (2008) Brewery wastewater treatment using aircathode microbial fuel cells. Applied Microbiology and Biotechnology 78(5), 873-880.

Huang, L. and Angelidaki, I. (2008) Effect of humic acids on electricity generation integrated with xylose degradation in microbial fuel cells. Biotechnology and Bioengineering 100(3), 413-422.

Huang, L., Cheng, S., Rezaei, F. and Logan, B.E. (2009) Reducing organic loads in wastewater effluents from paper recycling plants using microbial fuel cells. Environmental Technology 30(5), 499-504.

Ishii, S.i., Shimoyama, T., Hotta, Y. and Watanabe, K. (2008) Characterization of a filamentous biofilm community established in a cellulose-fed microbial fuel cell. Bmc Microbiology 8.

Kim, J.R., Jung, S.H., Regan, J.M. and Logan, B.E. (2007) Electricity generation and microbial community analysis of alcohol powered microbial fuel cells. Bioresource Technology 98(13), 2568-2577.

Kim, K.-Y., Yang, W. and Logan, B.E. (2015) Impact of electrode configurations on retention time and domestic wastewater treatment efficiency using microbial fuel cells. Water Research 80, 4146.

Lee, K.-y., Ryu, W.-s., Cho, S.-i. and Lim, K.-h. (2015) Comparative study on power generation of dual-cathode microbial fuel cell according to polarization methods. Water Research 84, 43-48. Liu, H., Cheng, S.A. and Logan, B.E. (2005) Production of electricity from acetate or butyrate using a single-chamber microbial fuel cell. Environmental Science \& Technology 39(2), 658-662. Liu, Z., Liu, J., Zhang, S. and Su, Z. (2009) Study of operational performance and electrical response on mediator-less microbial fuel cells fed with carbon- and protein-rich substrates. Biochemical Engineering Journal 45(3), 185-191. 
Lobato, J., Canizares, P., Jesus Fernandez, F. and Rodrigo, M.A. (2012) An evaluation of aerobic and anaerobic sludges as start-up material for microbial fuel cell systems. New Biotechnology 29(3), 415-420.

Logan, B.E., Hamelers, B., Rozendal, R.A., Schrorder, U., Keller, J., Freguia, S., Aelterman, P., Verstraete, W. and Rabaey, K. (2006) Microbial fuel cells: Methodology and technology. Environmental Science \& Technology 40(17), 5181-5192.

Lovley, D.R. (2008) The microbe electric: conversion of organic matter to electricity. Current Opinion in Biotechnology 19(6), 564-571.

M., R., Agler, M.T., J.J., F., A., V. and L.T, A. (2010) Integrating BES in the wastewater and sludge treatment line, International Water Association, London, UK, Bioelectrochemical System: From Extracellular Electron Transfer to Biotechnological Application, Eds.: Rabaey K., Angenent L. T., Schröder U. and Keller J. .

Makinen, A.E., Lay, C.-H., Nissila, M.E. and Puhakka, J.A. (2013) Bioelectricity production on xylose with a compost enrichment culture. International Journal of Hydrogen Energy 38(35), 15606-15612.

Oh, S.E. and Logan, B.E. (2005) Hydrogen and electricity production from a food processing wastewater using fermentation and microbial fuel cell technologies. Water Research 39(19), 4673-4682.

Pant, D., Van Bogaert, G., Diels, L. and Vanbroekhoven, K. (2010) A review of the substrates used in microbial fuel cells (MFCs) for sustainable energy production. Bioresource Technology 101(6), 1533-1543.

Penteado, E.D., Fernandez-Marchante, C.M., Zaiat, M., Cañizares, P., Gonzalez, E.R. and Rodrigo, M.A. (2016) Influence of sludge age on the performance of MFC treating winery wastewater. Chemosphere 151, 163-170

Rabaey, K., Lissens, G., Siciliano, S.D. and Verstraete, W. (2003) A microbial fuel cell capable of converting glucose to electricity at high rate and efficiency. Biotechnology Letters 25(18), 15311535.

Rabaey, K. and Verstraete, W. (2005) Microbial fuel cells: novel biotechnology for energy generation. Trends in Biotechnology 23(6), 291-298.

Rezaei, F., Xing, D., Wagner, R., Regan, J.M., Richard, T.L. and Logan, B.E. (2009) Simultaneous Cellulose Degradation and Electricity Production by Enterobacter cloacae in a Microbial Fuel Cell. Applied and Environmental Microbiology 75(11), 3673-3678.

Rodrigo, M.A., Canizares, P., Garcia, H., Linares, J.J. and Lobato, J. (2009a) Study of the acclimation stage and of the effect of the biodegradability on the performance of a microbial fuel cell. Bioresource Technology 100(20), 4704-4710.

Rodrigo, M.A., Canizares, P. and Lobato, J. (2010) Effect of the electron-acceptors on the performance of a MFC. Bioresource Technology 101(18), 7014-7018.

Rodrigo, M.A., Canizares, P., Lobato, J., Paz, R., Saez, C. and Linares, J.J. (2007) Production of electricity from the treatment of urban waste water using a microbial fuel cell. Journal of Power Sources 169(1), 198-204.

Rodrigo, M.A., Cañizares, P., García, H., Linares, J.J. and Lobato, J. (2009b) Study of the acclimation stage and of the effect of the biodegradability on the performance of a microbial fuel cell. Bioresource Technology 100(20), 4704-4710.

Sun, G., Thygesen, A. and Meyer, A.S. (2015) Acetate is a superior substrate for microbial fuel cell initiation preceding bioethanol effluent utilization. Applied Microbiology and Biotechnology 99(11), 4905-4915.

Virdis, B., Rabaey, K., Rozendal, R.A., Yuan, Z. and Keller, J. (2010) Simultaneous nitrification, denitrification and carbon removal in microbial fuel cells. Water Research 44(9), 2970-2980.

Virdis, B., Rabaey, K., Yuan, Z. and Keller, J. (2008) Microbial fuel cells for simultaneous carbon and nitrogen removal. Water Research 42(12), 3013-3024. 

treatment. Bioresource Technology 117, 172-179. 